\title{
EDUCAÇÃO FÍSICA ESCOLAR: TEMOS O QUE ENSINAR?
}

\author{
Ana Cristina ARANTES
}

No momento em que vemos se aproximar o final de um período, tempo em que todos se preparam para olhar as coisas que viveram ou sentiram, e, retomando fôlego também se propõem a estabelecer e refazer metas de vida num ritual que se repete ano a ano, como nos aponta Mircea Elíade, em sua obra "O sagrado e o profano" nos encontramos aqui, para discutir assuntos e temas sobre Educação Escolar e Educação Física, na tentativa de levantar seu conteúdo, validade e prática.

Neste sentido, a minha fala não poderia deixar de considerar os fatos que estamos assistindo; as transformaç̃̃es mundiais, as mudanças políticas que resultam das interaçð̃es humanas.

Também não posso deixar de considerar as notícias que recebemos e que somos quase que obrigados a aceitar.

Entretanto, quando estamos diante de uma classe de alunos, a nossa aula se reveste de um momento mágico, e especial. Representa um "recorte" dentro deste contexto. Ela possui um tempo, um objetivo, um conteúdo, e uma especificidade ímpar, embora não desconsidere a realidade e o meio.

É na aula que muitos momentos e movimentos pertencem exclusivamente àquela hora.

É ali na rua, na quadra, no ginásio, no chão de terra batida, que certamente será dada a oportunidade para que os alunos vivenciem a motricidade, apreciem e participem das atividades e certamente, é ali também que se produzirá conhecimento.

Em um recuzido espaço de tempo - cinquenta minutos, duas a três vezes por semana nos reunimos para "viver", jogar, cambalhotar. Isto nos parece algo maravilhoso - poder proporcionar a corpos e almas a infinita possibilidade de se auto-conhecer, de compreender regras, de estabelecer valores.

Auxiliados por um professor cuidadoso, competente, e afetivo, as trocas se efetuarão em todos os sentidos, em todos os momentos.

É bem verdade, que o professor deve de antemão ter escolhido o que irão juntos realizar ele e seus alunos; ter considerado os pequenos corações que o aguardam, para a implementação de mais um dia de prática; ele, o mestre, elabora sua aula, prevê as dificuldades e tenta adivinhar e fazer cumprir as expectativas dos que na quadra estarão.

Dependendo de sua maturidade, e inclinação pessoal, proporcionará experiências inigualáveis, onde a alegria e a verdadeira compreensão do que está se realizando andam "paripasso" Então o professor ensina: realiza a sua vocação; reafirma dia a dia a sua missão.

Os alunos por sua vez, gostam ou desgostam daquela figura humana, vêem nela algum referencial para se orientar, para se guiar. No professor, serão "coladas" uma série de expectativas e desejos os quais ele sem saber deverá cumprir. Que mágica é esta onde a aprendizagem ocorre de forma "implícita"? - uma vez que inúmeros fatores estarão presentes sem estarem declarados? - um gesto, um olhar, a forma de conduzir a sessão, o tom de falar e a maneira de agir? - compreende-se então, que o professor dentro de sua esfera de atuação, é um formador de atitudes, de opiniơes e de conduta. Além do conteúdo específico de sua disciplina ele Ensina.

Mas, se a formalidade de uma aula representa sobretudo um momento específico das interaçðes humanas, o professor ao longo de sua trajetória também aprendeu.

\footnotetext{
"Escola de Educação Física da Universidade de São Paulo.
} 
Por muitas vezes teve que repensar sua fala, o conteúdo escolhido, sua maneira de orientar. Por muito tempo, alguém o preocupou, precisou reestruturar a sua concepção de vida e sua prática pedagógica. Assim sendo, ele também aprendeu. 0 aluno neste sentido, se transformou em professor!

$\mathrm{E}$, na medida, que os anos passam, o docente, produto desta rede das interaç̃es humanas, é uma possível síntese deste processo mútuo onde quer que ele vá, levará seus discípulos consigo.

Colocados estes fatos, pergunto : Temos o que ensinar?

À primeira vista, cabe ao professor esta tarefa. O exato sentido de "ENSEÑAR" em espanhol significa mostrar; mostrar o caminho... Então responderemos que sim. Temos o que ensinar!

Dentro de nossa área de conhecimento, múltiplas e infindáveis combinaçð̃es de jogos, de brincadeiras que discutidas, poderão auxiliar a formação do conceito da motricidade humana. Adequadamente estruturados deverão desencadear os processo mentais e físicos.

Sobre todas coisas que já escreveu, programas e propostas, do pueril ao mais complexo, encontramos nos estudiosos e em suas obras, o conteúdo que nos pode esclarecer quais as tarefas que devemos implementar e isto parece "simples" Entretanto, sabemos que a docência não se resume em "passar fórmulas", é seguramente muito mais que isto.

E se tratando do Ensino Escolar, há uma série de expectativas e de rituais a serem cumpridos.

Neste "recorte" do cotidiano - a aula, como realizá-los?

Será que daremos conta?

Neste momento de dúvida precisamos afirmar que SIM.

Considerando todas as nossas dificuldades, em compreender, hierarquizar e sintetizar fatos, escolher o que ministrar, urge que tomemos atitude, no sentido de intervir e de mudar.

Mesmo que seja dentro de nosso âmbito, cinqüenta ou cem alunos, é preciso tomar posição!

Sempre disse que 0 professor é revestido de duas palavras: TRANSFORMAÇÃO e ESPERANÇA. Mesmo que não se tenha claro onde iniciar, é preciso fazer algo, reunir, conversar, estudar, formular, aplicar e avaliar.

Faz-se necessário que, sobrepujando as dificuldades naturais, - cumpramos nossa função - a de ensinar.

Ao escrever estas linhas, estou considerando todas as misérias sociais. Estou sabendo das dificuldades, mas é preciso fazer, é preciso mostrar alguma alternativa, é preciso ter grandes olhos e grandes ouvidos para analisar as coisas ao nosso redor, ser sensível e justo, competente e amável

É necessário recomeçar todos os dias. A estrada é infinita mas é preciso dar o primeiro passo.

TEMOS O QUE ENSINAR? Sim deverá ser a resposta.

Através da Educação Física na Escola, precisamos ensinar e aprender conceitos sobre a motricidade humana, aprender a viver a solidariedade, apreciar sinceramente a competência, valorizar a justiça, favorecer a criação de talentos e liderança, dar oportunidade aos desfavorecidos àqueles que têm dificuldade e, dentre tantos outros valores, cultivar a alegria, a auto estima e o conhecimento.

Considerando o que aprendi com as pessoas e com todos os meus alunos, agradeço a todos aqueles que no cotidiano ao longo destes anos, me revelaram coisas, e me ensinaram a escrever estas palavras.

Sinceramente. Obrigada! 